\title{
Done good
}

\section{A L Caplan}

\section{Correspondence to}

Dr A L Caplan, Division of Medical Ethics, NYU Langone Medical Center, 227 East 30th Street, New York, NY 10016, USA;

Arthur.Caplan@nyumc.org

Received 30 September 2014 Revised 7 October 2014 Accepted 17 October 2014
To cite: Caplan AL. J Med Ethics 2015;41:25-27.

\section{ABSTRACT}

How did bioethics manage to grow, flourish and ultimately do so well from a very unpromising birth in the 1970s? Many explanations have been advanced. Some ascribe the field's growth to a puzzling, voluntary abnegation of moral authority by medicine to nonphysicians. Some think bioethics survived by selling out to the biomedical establishment—public and private. This transaction involved bestowing moral approbation on all manner of biomedicine's doings for a seat at a well-stocked funding table. Some see a sort of clever intellectual bamboozlement at work wherein bioethicists pitched a moral elixir of objective expertise that the morally needy but unsophisticated in medicine and the biological sciences were eager to swallow. While each of these reasons has its defenders, I think the main reason that bioethics did well was that it did good. By using the media to move into the public arena, the field engaged the public imagination, provoked dialogue and debate, and contributed to policy changes that benefitted patients and healthcare providers.

When I first got interested in bioethics, I was a philosophy graduate student at Columbia University in the late 1970s. I remember very clearly being told by my teachers and fellow students not to identify myself as a 'bioethicist'. That was akin to saying you were a 'Rosicrucian', an alcoholic, or even worse, someone interested in the philosophy of education. Times have certainly changed.

Bioethics today is riding high in the saddle; shaping public health policy, exercising oversight of biomedical research, consulted by powerful organisations for ethical help and setting normative rules for the diagnosis and treatment of patients. It has spread worldwide, from a few small think tanks and medical school programmes located in the USA. Philosophy, on the other hand, is bogged down by an utter inability to respond to sexism and racism, boorish behaviour by some of its influential leading lights and a growing indifference on the part of academic peers to its input or its output. ${ }^{12}$

So how did it happen that the bastard child of philosophy and, truth be told, of theology as well, grew up to overshadow its parental disciplines? Understanding the prosperity of a field that few in the 1970s would have thought would last more than a decade is useful for understanding what it means to do good medical ethics. For me, doing good medical ethics requires doing good by doing medical ethics. How bioethics and its somewhat less expansive subpart, medical ethics, ${ }^{\mathrm{i}}$ came to be doing well is by having done good.

Bioethics in America in the mid-1970s was distinguished by a number of features that any objective observer at the time would have been certain spelled its imminent doom. It had no standing within the academy. Those interested in its issues were scattered all over the intellectual landscape. No funding entity, public or private, gave a damn about it. It had no canon, no acknowledged theoretical grounding, almost no historical forbears and no training programmes. It was viewed, when it was viewed at all, by physicians and healthcare providers with indifference and by leading scientists with outright hostility mixed with a healthy dose of mirth. Those few hearty intellectual souls who wanted to engage bioethical topics had to do so by travelling to the somewhat monastic precincts of the Hastings Center or the Kennedy Institute where they could be assured a rapt audience for their writings and musings that consisted entirely of one another. No journal of any scholarly repute would publish anything by a bioethicist, much less from a group of them, so they had to start their own publication outlets. ${ }^{3}$

It was the worst of times. It was also the best of times.

Back then, lots of academics working in the humanities claimed to be working on important conceptual issues. But this work, at least in ethics, still focused on metaethical disputes, and was of no use to those facing actual ethical choices. Early medical ethicists, on the other hand, were engaging with real-world crises, such as the Tuskegee study, allowing experiments with in vitro fertilisation or the Seattle 'God Committee'. Bioethics was proudly interdisciplinary, open to the integration of facts and values and listening hard to its doubters and critics in terms of what they needed by way of products. It was a field that knew it would live or die by the calibre of the scholarship it produced, and it tried hard to produce a high calibre of work. ${ }^{4}$ It was a field whose timing was impeccable -new problems and challenges emerged one after another in rapid succession fuelled by technological advances creating a demand for somebody,

${ }^{\mathrm{i}}$ Bioethics is the full-throated study of ethical problems in medicine, nursing, public health, the allied health professions and the biomedical sciences. Medical ethics I take to be focused on physicians. I will use 'bioethics' in this paper to refer to both. 
anybody, to provide thoughtful input into their management. ${ }^{5}$ It was a field that, notably, attracted few, but among the thin ranks were many intellectual giants.

At birth, bioethics might have flourished or died. Some of the factors that seemed to put it most at risk turned out to be exactly the features that allowed it to grow.

But bioethics, even as it began to grow in the late 1970s with new programmes created at medical schools, interest outside the northeast USA, acceptance of its writings and topics into mainstream journals, the admission of bioethicists into the inner sanctums of academic medicine still faced a tenuous future. ${ }^{6}$ Could it survive its adolescence without a firm academic home and plenty of hostility on display from traditional humanities disciplines as well as the professions?

We know it did survive. During the 1980s and 1990s it grew rapidly in terms of resources, practitioners, publications, professional societies and other measures of academic success. But, why? I don't think the extant explanations for the field's doing well are adequate.

Some ascribe the growth to the puzzling abnegation of moral authority by medicine to the upstart field. ${ }^{6-8}$ Some see making bioethics surviving intellectual puberty by a decision to sell out to the biomedical establishment; a trade which involved bestowing moral approbation on biomedicine's doings for a seat at the funding table among biomedical luminaries. ${ }^{9} 10$ Some see a sort of intellectual bamboozlement wherein bioethicists sold a moral elixir of objective expertise that the morally needy in medicine and science were eager to swallow. ${ }^{11} 12$

It is true that medicine did yield some authority over its own domain to outsiders. But, this occurred in pursuit of intellectual help from a medical profession that was well aware it needed that help, and thoughtfully and willingly invited outsiders in to render it. ${ }^{13}$ And it is also true that the tools of principlism and consequentialism $^{14}{ }^{15}$ seemed to provide expertise relief from what K Danner Clouser of the early leading lights in the field described as an activity relying on 'a mixture of religion, whimsy, exhortation, legal precedents, various traditions, philosophies of life, miscellaneous moral rules and epithets'. ${ }^{16}$

These explanations are partially accurate, but only partially. A crucial step in the transformation of bioethics from fragile newborn (early 1970s), to cranky adolescent (late 1970s early 1980s), to full-blown flourishing adulthood (mid-1980s to present), was its willingness to move into the public arena. And the route to the public arena ran right through the media.

Bioethics, when I entered the field in the late 1970s, was operating under the assumption that it had to find academic legitimacy or, rather, legitimacy in the eyes of some element of the academy. It did. It succeeded in being thoughtful, rigorous, scholarly and erudite enough to crack open the doors of some philosophy departments, many top-ranked medical schools and a few law schools where standing was granted.

But other fields had made that journey before bioethicsnotably thanatology, social medicine and behavioural sciences. None of these survived with the vigour that characterises bioethics. The difference is that bioethics gained social legitimacy by not following the British analytical philosophy tradition into the ivory tower, but, rather, the Socratic tradition of engaging the public in the 'marketplace'.

My own work in bioethics illustrates an effort to push bioethical discourse into the media and, thus, into the marketplace of politics and policy. As I began to fully engage the field in the early 1980s as a philosopher trained in the analytical tradition, it nevertheless, seemed to me that it made no sense for bioethics to simply be an ivory tower academic field even in the broadest sense of that term. The only reason I could see for doing applied work in bioethics was to improve the well-being of research subjects and patients and to be of use to providers and the public as they wrestled with the moral challenges generated by medical advances or by disparities in the availability of medical services. This work required both academic inquiry and engagement with the public. The way I could see for accomplishing that end was to push bioethical matters into the media-at that time television, newspapers, radio and news magazines.

I knew nothing about how the media operated, but decided to rectify that by offering to give some lectures at the Columbia University School of Journalism. This proposal was accepted and I got to learn quite a bit about how journalism worked, how it was organised and to meet some young practitioners who would go on to distinguished careers in the media as medical and science reporters and editors. A little later I also had a chance to join the board of the Poynter Institute, a highly regarded think tank in Florida, which did continuing education work with journalists. Here too it was possible to convince editors and producers that bioethics was not simply an afterdinner mint but often the core subject of interest to those following stories about healthcare and the biomedical sciences.

These experiences helped prepare me to interact with journalists. When I had the chance I was not shy about telling them when an issue such as the first artificial heart, the Baby M surrogacy case or the Baby Fae baboon heart transplant experiment presented itself that the ethical issues raised were as crucial for the public to understand as the science. I also began to try to write for the general public through 'op eds', keeping in mind the warnings of my elders that popularising was a dangerous role for an academic seeking to remain an academic.

I found myself continuing to be unhappy, however, or having to work through journalists to highlight ethical issues. When I moved in 1987 to the University of Minnesota, I decided to explore the possibility of writing a regular column on bioethics for one of the local newspapers, the St Paul Pioneer Press. The editors there decided to take a chance on the idea, and for a year, I wrote a weekly column that discussed all manner of bioethical issues; from the bedside, to access, to public health, to international issues. Reader feedback was strong, often heated and steady. The column was then bought for syndication by King Features syndicate which eventually ran the column in more than 50 newspapers in many major media outlets.

The column drew the attention of many science and medicine reporters both for story ideas and for using me as a commentator on topics they were exploring. As the internet grew it became easier to both track stories to write about and see the influence of commentary and opinion reverberate through the media and into the thinking of the public and, therefore, into the concerns of politicians and regulators. ${ }^{17}$

The decision to pull bioethics out of the ivory tower and into the messy world of the 'marketplace' was initially greeted with mixed reviews by peers. ${ }^{18}$ Some in philosophy saw outreach through the media to the public as inconsistent with rigorous inquiry, and a 'cheapening' of what, by necessity, was a rich and nuanced area of analysis. Some saw it as portraying bioethics in an overly simplistic light. Some did see the public turn as empowering for patients and subjects. Still others saw nothing but vanity and self-aggrandisement. By the time social media burst on to the scene in the mid-2000s, opening a new world of blogs and websites and somewhat diminishing the authority and impact of the mainstream media, bioethics' responsibility to engage in public discourse was taken for granted and even extolled by national commissions and panels. 
Obviously, far more was occurring in bioethics during the 1980s and 1990s than a movement towards public engagement through the media. This movement was, however, going on and happening in a way that drove bioethics into dialogue in the seminar room or grand rounds and on the editorial pages, around the 'water cooler', in Hollywood, from the pulpit, and with a favourable eye from the judiciary and legislators.

I think the success of bioethics is partly attributable to its public turn. The field showed itself, if not capable of always producing consensus or answers, at least able to raise questions and concerns. And the resulting public conversation and debate led to the creation of commissions, laws, court rulings and professional society policies that positively impacted daily human life.

There are many ways to do good bioethics. One crucial way is to do good by doing bioethics. The practical impact of bioethics on public discourse and, thus, public policy goes a long way towards explaining why bioethics has done well.

\section{Competing interests None.}

Provenance and peer review Commissioned; internally peer reviewed.

\section{REFERENCES}

1 Warman M. Stephen Hawking tells Google 'philosophy is dead'. The Telegraph, 17 May 2011. http://www.telegraph.co.uk/technology/google/8520033/ Stephen-Hawking-tells-Google-philosophy-is-dead.html

2 Schmidt P. The man who ranks philosophy departments now rankles them, too. The Chronicle of Higher Education, 26 Sep 2014. http://chronicle.com/article/ The-Man-Who-Ranks-Philosophy/149007/

3 Baker B. Before bioethics. New York: Oxford, 2013.

4 Callahan D. Bioethics as a discipline. Stud Hastings Cent 1973;1(1):66-73.

5 Jonsen A. The birth of bioethics. New York: Oxford, 1998.

6 Rothman DJ. Strangers at the bedside. New York: Basic, 1991.

7 Lerner B. The good doctor. Boston: Beacon, 2014.

8 Belkin G. Death before dying. New York: Oxford, 2014.

9 Stevens MLT, Bioethics in America Baltimore. Johns Hopkins, 2003.

10 Koch T. Thieves of virtue: when bioethics stole medicine. Cambridge: MIT Press, 2012.

11 Fox R, Swazey J. Observing bioethics. New York: Oxford, 2008.

12 Evans JH. The history and future of bioethics. New York: Oxford, 2011.

13 Toulmin S. How medicine saved the life of ethics. Perspect Biol Med 1982;25 (4): $736-50$.

14 Singer P. Practical ethics. New York: Cambridge University Press, 1979.

15 Beauchamp TL. J Childress Principles of Biomedical Ethics. New York: Oxford, 1979.

16 Clouser KD. Bioethics and philosophy. Hastings Cent Rep 1993;23(6):6-9.

17 Kruvand M. Bioethicists as Expert Sources in Science and Medical Reporting. Newspaper Res J 2009;30(3):26-41.

18 Kruvand M. 'Dr. Soundbite': The Making of an Expert Source in Science and Medical Stories. Sci Commun 2012;34(5):566-91. 